\title{
Role of pleural fluid-serum protein carbonyl gradient in differentiating exudative and transudative effusions
}

\author{
Raghumoy Ghosh'1, Kheya Mukherjee², Saumyajit Maiti ${ }^{3}$, Debojyoti Bhattacharjee ${ }^{4}$, \\ Shubho Chowdhuri ${ }^{5}$ \\ ${ }^{1}$ Senior Resident, Department of Biochemistry, All India Institute of Medical Science, Jodhpur, Rajasthan, India, \\ ${ }^{2}$ Associate Professor, Department of Microbiology, ID \& BG Hospital, Kolkata, West Bengal, India, ${ }^{3}$ Demonstrator, \\ ${ }^{4}$ Associate Professor, Department of Biochemistry, IPGME\&R and SSKM Hospital, Kolkata, West Bengal, India, ${ }^{5}$ Intern, \\ Murshidabad Medical College and Hospital, West Bengal, India
}

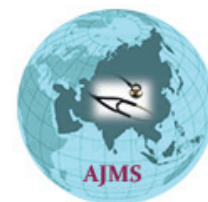

A B S TR A C T

Background: Pleural effusions often cause a diagnostic dilemma. The first step in the evaluation of pleural effusions is the distinction between exudates and transudates. Aims and Objectives: The current study was designed to distinguish these two broad subgroups of pleural effusions, based on the protein carbonyl gradient between pleural fluid and serum. Materials and Methods: Forty-four exudative and thirty-six transudative pleural effusion cases based on clinical findings and evaluation by Light's criteria were selected. Protein carbonyl was measured by established photometric method using dinitrophenylhydrazine (DNPH) method in pleural fluid and serum of all the cases. Results: Oxidative stress, estimated by the protein carbonyl gradient between pleural fluid and serum, was found to be higher in exudates when compared to transudates. No significant difference was existent between exudates of different aetiology. However, the gradient was higher in exudates from males compared to females. No such difference was found among transudates. Conclusions: Carbonyl stress being a simple easily measurable biochemical parameter, pleural fluid to serum protein carbonyl gradient may serve as a useful tool for differentiating pleural effusions based on pathogenesis.

Key words: Protein Carbonyl; Exudates; Transudates

\section{Access this article online}

Website:

http://nepjol.info/index.php/AJMS DOI: 10.3126/ajms.v11i6.30579

E-ISSN: 2091-0576

P-ISSN: $2467-9100$

Copyright (c) 2020 Asian Journal of Medical Sciences

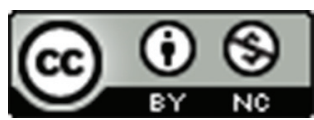

This work is licensed under a Creative Commons Attribution-NonCommercial 4.0 International License.

\section{INTRODUCTION}

Pleural effusions have classically been divided into transudative and exudative types. ${ }^{1} \mathrm{~A}$ transudative pleural effusion develops when there occurs an alteration in systemic factors influencing the formation and absorption of pleural fluid leading to accumulation of fluid. Exudative pleural fluid results from increased permeability of pleural surface or pulmonary capillaries due to local inflammation. ${ }^{2}$ Differentiation of bio-fluid into transudates and exudative effusions is the initial step in diagnostic algorithm of the fluid for diagnostic and therapeutic purpose. ${ }^{3}$ Physical and radiographic findings are not sensitive tools in differentiating these two fluids. Currently the most important diagnostic criteria for such differentiation are Light's criteria. ${ }^{4}$ Carbonyl (CO) groups (aldehydes and ketones) are produced on protein side chains especially upon amino acids Proline, Arginine, Lysine and Threonine when they are oxidised. These moieties are chemically stable, which is useful for both their detection and storage. Protein carbonyl content is actually the most general indicator and by far the most commonly used marker of protein oxidation..$^{5-8}$ Pleural fluid examination among 19 lung cancer patients showed elevated protein carbonyl concentrations compared to benign inflammatory cases. ${ }^{9}$ Similar prospective study 
conducted upon 70 pulmonary and extra pulmonary tuberculosis cases had shown increased serum protein carbonyl levels among patients compared to the control group. ${ }^{10}$ These oxidant molecules could be implicated in the local inflammatory response existing in exudative pleural effusions. A study conducted to detect pulmonary oxidant-antioxidant imbalance in Bronchoalveolar lavage (BAL) fluid derived from epithelial lining fluid of Adult Respiratory Distress Syndromes (ARDS) cases, indicated an increase in oxidative modification of proteins in form of carbonyl products. ARDS patients had derived almost five times the level of oxidation of the proteins compared to control subjects. ${ }^{11}$ These results showed an accumulation of functionally altered oxidatively modified proteins in BAL fluid of ARDS patients and in untreated at-risk patients. Consequently, relevant systems and functions in the respiratory tract such as the protease/antiprotease balance, surfactant or mucus had become dysfunctional. Based on these results, it can be proposed that altered pulmonary protein functions by carbonylation contribute considerably in the pathogenesis of ARDS. ${ }^{11-13}$ Light's criteria, differentiates almost accurately $99 \%$ of the pleural effusion cases into transudative and exudative. Numerous other biochemical parameters like pleural fluid cholesterol level, pleural fluid to serum bilirubin ratio, pleural fluid to serum cholinesterase ratio, biophysical parameters like pleural fluid viscosity, modern radiological investigations like computed tomography, cell free DNA assay, capillary electrophoresis study and oxidative stress panel analysis of the pleural fluid, have been attempted for the purpose of differentiating between transudative and exudative effusions. ${ }^{1-22}$ However, none of these parameters explain the structural and functional changes that occur within the pleural parenchymal protein that are associated with the pathogenesis of accumulation of fluid within the pleural cavity in diverse pathological condition. So far, no study has been performed to differentiate between transudative and exudative types of effusions by comparing the protein carbonyl levels of pleural fluids arising due to various etiologies that could serve as an important differentiating marker. With this background, the study was conducted this study in order to explore efficacy of this investigation modality based on protein carbonyl level estimation.

\section{MATERIALS AND METHODS}

A hospital-based, randomized, cross-sectional study was conducted upon pleural fluid and blood samples obtained from patients admitted in the Department of Chest Medicine in a tertiary care hospital in Kolkata, West Bengal. Pleural fluids were collected aseptically from patients via thoracocentesis. Fluids upon biochemical analysis at the Department of Biochemistry were designated as exudates $(n=44)$ if it satisfied any one of the Light's criteria like pleural fluid: serum protein ratio $>0.5$, pleural fluid: serum Lactate Dehydrogenase (LDH) ratio $>0.6$ or pleural fluid $\mathrm{LDH}>66 \%$ of upper limit of serum LDH level. Otherwise, samples were termed as transudates $(\mathrm{n}=36)$. All cases belonged to the same city of Kolkata, had similar socio-economic background and were exposed to similar chronic risk factors like smoking, alcoholism and environmental pollution. Exudative pleural effusion consisted of 28 males and 18 females. Cases chosen consisted of tuberculosis, bronchogenic carcinoma, parapneumonic effusion, fungal infection and restrictive lung disease including collagen vascular disease. Transudative samples (18 males: 18 females) were collected from patients suffering from congestive cardiac failure, cirrhosis of liver with portal hypertension and nephrotic syndrome, constrictive pericarditis and malnutrition. The cases were matched based on age, sex, duration of development of pleural effusion, severity of state of disease. Patients with history of pneumothorax, interstitial lung disease, hydrothorax, granulomatous disease, prolonged diuretic therapy, etc were excluded from the study. Blood samples collected from these same patients from the antecubital vein were subjected to separation of serum following centrifugation at $3000 \mathrm{rpm}$.

The study principles and procedures adhered to the ethical standards formulated in the (1975, revised in 1983) Helsinki declaration. Protein-carbonyl level in pleural fluid and serum was measured biochemically by Dinitrophenylhydrazine (DNPH) method (Levin et al). ${ }^{23}$ Protein estimation in pleural fluid and serum was done by Biuret method. ${ }^{24}$ Lactate Dehydrogenase (LDH) enzyme levels were estimated by Modified IFCC method. ${ }^{25}$

\section{Statistical analysis}

Statistical analysis was performed using IBM SPSS Statistics 20 Windows. All values were expressed as mean \pm Standard Deviation (SD).Comparison of continuous variables between exudative and transudative groups were evaluated using Student's $t$ test. Categorical variables were compared using Pearson's chi-square test $(\chi 2)$ test. Probability value $\mathrm{p}<0.05$ was considered to be statistically significant at a confidence limit of 95\%. Receiver Operating Characteristic (ROC) Curve was drawn to depict the tradeoff between sensitivity and specificity for protein carbonyl as a differentiating marker between exudates and transudates. 


\section{RESULTS}

After fulfilling the inclusion and exclusion criteria 44 subjects were classified as having exudative pleural effusion based on Light's criteria. 36 cases were diagnosed to be in the transudative group. Statistically the matching of age and gender between these two groups was checked by independent' $\mathrm{t}$ ' test $(\mathrm{t}=5.994, \mathrm{p}<0.0001)$ and chi-square test $(\chi 2=1.5066, \mathrm{p}>0.05)$ respectively. The protein carbonyl levels of the pleural fluid and serum of individual transudative and exudative effusion samples were estimated. The values were expressed in terms of ratio of protein carbonyl content of pleural fluid to serum, per gram of protein per litre. In exudative cases the ratio $\left(R_{e}\right)$ was significantly higher (Mean \pm Standard Deviation: $0.72 \pm 0.09)$ than the ratio in transudative cases $\left(R_{t}\right)$ (Mean \pm Standard Deviation: $\left.0.34 \pm 0.1\right)$. It was seen that the ratio in exudates $\left(\mathrm{R}_{\mathrm{e}}\right)$ was significantly higher (Mean \pm Standard Deviation: $0.72 \pm 0.09$ ) than the ratio among transudative cases $\left(\mathrm{R}_{\mathrm{t}}\right)$ (Mean \pm Standard Deviation: $0.34 \pm 0.1$ ) (Table 1).

Among the exudative pleural effusion cases, $R_{e}$ levels were higher in males compared to females $(p<0.05)^{e}$. However,

\begin{tabular}{|c|c|c|c|}
\hline $\begin{array}{l}\text { Pleural fluid } \\
\text { sample type }\end{array}$ & $\begin{array}{l}\text { Ratio of pleural } \\
\text { protein carbonyl/ } \\
\text { gm protein/litre } \\
\text { to serum protein } \\
\text { carbonyl/gm } \\
\text { protein/litre }\end{array}$ & $\mathrm{t}$ value & $P$ value \\
\hline $\begin{array}{l}\text { Exudative }\left(R_{e}\right) \\
(\text { Mean } \pm S D)(n=44)\end{array}$ & $0.720 \pm 0.094$ & 17.87 & $<0.001$ \\
\hline $\begin{array}{l}\text { Transudative }\left(R_{t}\right) \\
(\text { Mean } \pm S D)(n=36)\end{array}$ & $0.344 \pm 0.101$ & & \\
\hline
\end{tabular}

The mean difference is significant at the 0.05 level

\begin{tabular}{|c|c|c|c|c|}
\hline \multirow[t]{2}{*}{$\begin{array}{l}\text { Pleural } \\
\text { fluid } \\
\text { sample } \\
\text { type }\end{array}$} & \multicolumn{2}{|c|}{$\begin{array}{l}\text { Ratio of pleural protein } \\
\text { carbonyl/gm protein/ } \\
\text { litre to serum protein } \\
\text { carbonyl/gm } \\
\text { protein/litre }\end{array}$} & \multirow[t]{2}{*}{$t$ value } & \multirow[t]{2}{*}{$p$ value } \\
\hline & Male & Female & & \\
\hline $\begin{array}{l}\text { Exudative } \\
(\text { Mean } \pm S D) \\
(n=44)\end{array}$ & $\begin{array}{c}0.74 \pm 0.08 \\
(n=28)\end{array}$ & $\begin{array}{c}0.678 \pm 0.11 \\
(n=16)\end{array}$ & 2.15 & $<0.05$ \\
\hline $\begin{array}{l}\text { Transudative } \\
(M e a n \pm S D) \\
(n=36)\end{array}$ & $\begin{array}{c}0.35 \pm 0.08 \\
(n=18)\end{array}$ & $\begin{array}{c}0.34 \pm 0.12 \\
(n=18)\end{array}$ & 0.00 & 1.0 \\
\hline
\end{tabular}

no such difference existed in the $\mathrm{R}_{\mathrm{t}}$ levels of transudative male and female cases (Table 2).

The difference between $\mathrm{R}_{\mathrm{e}}$ and $\mathrm{R}_{\mathrm{t}}$ was statistically significant across all age groups the study had taken into account (Table 3).

Based on the results of ROC curve, a cut-off ratio value of $>0.49$ yielded maximum sensitivity and specificity for basic differentiation of two types of pleural collection (Figure1).

\section{DISCUSSION}

A number of bedside biochemical tests based on oxidative stress have been established to classify pleural effusions into exudates and transudates on a point of care basis. Studies conducted to show the role of oxidative stress parameters in 48 malignant exudative pleural fluids have found increased levels of oxidative stress markers like malondialdehyde, compared to benign controls. ${ }^{26}$ Similar studies in 60 patients with pleural effusion of diverse aetiologies had demonstrated a statistically significant $(\mathrm{p}<0.05)$ rise in mean pleural fluid malondialdehyde in exudates in comparison to transudates. ${ }^{27}$

Similarly, in our study it was observed that exudative pleural fluids presented with an elevated levels of oxidative stress parameter in form of protein carbonyl, compared to transudative effusions (Table 1). The increased ratio of pleural fluid/serum protein carbonyl gradient in exudates probably represented an increased local production of free radicals. The origin of this oxidative stress in the pleural fluid may be related to the pathogenesis underlying disease process. Local production of oxidants in the pleural cavity has not been extensively studied. In vitro evidence in animal models indicated that reactive oxygen and nitrogen species may be implicated in the pathogenesis of asbestos-related pleural effusions. ${ }^{27}$ Various oxidants play an important dual role in carcinogenesis, serving both as tumor initiators, tumor promoters as well as regulators of gene expression. ${ }^{28}$ This has been shown both in lung cancer and in other malignancies. Tuberculosis had been associated with increased levels of several markers of oxidative stress and decreased antioxidant capacity. ${ }^{29}$ All of the above mentioned disease processes may contribute to the increased oxidative stress production when the pleural cavity is involved. Pleural Mesothelial cells (PMC) are responsible for release of oxidants in pleural space infections. ${ }^{30}$ The PMC acting as central component of the immune responses of the pleura is thought to play an important role in defence mechanisms against bacterial 
Table 3: Variation ofRatio of pleural protein carbonyl/gm protein/litre to serum protein carbonyl/gm protein/litre in different age groups

\begin{tabular}{lcccc}
\hline $\begin{array}{l}\text { Age groups } \\
\text { (In years) }\end{array}$ & $\begin{array}{c}\text { Exudative cases } \\
\text { (mean } \pm \text { SD) }\end{array}$ & $\begin{array}{c}\text { Transudative cases } \\
\text { (mean } \pm \text { SD) }\end{array}$ & t value & p value \\
\hline $18-40$ & $0.688 \pm 0.091$ & $0.240 \pm 0.117$ & 7.81 & $<.0001$ \\
$40-60$ & $0.775 \pm 0.083$ & $0.314 \pm 0.089$ & 14.3 & $<.0001$ \\
$\geq 60$ & $0.675 \pm 0.047$ & $0.379 \pm 0.009$ & 28.65 & $<.0001$ \\
\hline
\end{tabular}

The mean difference is significant at the 0.05 level

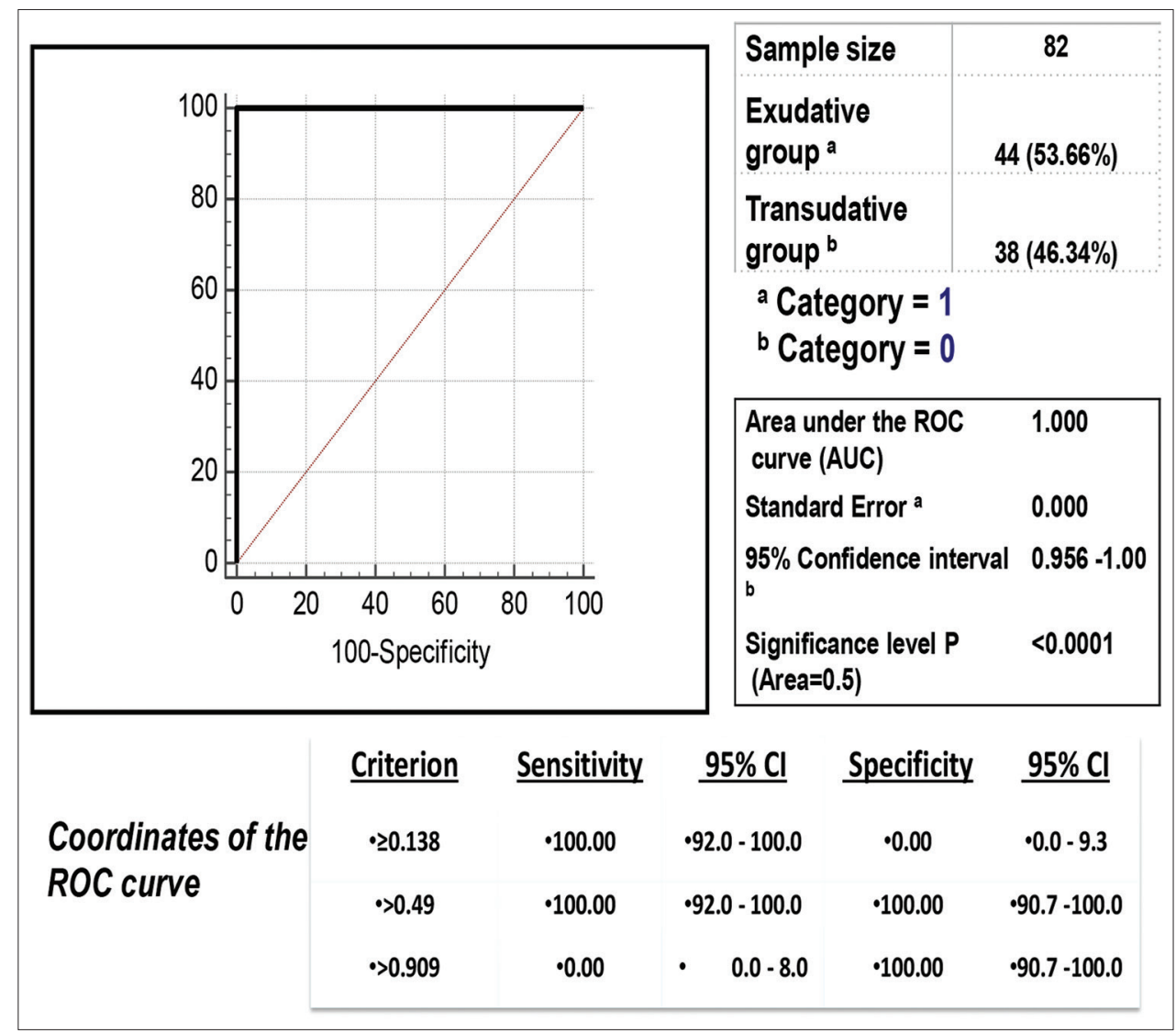

Figure 1: ROC curve analysis to identify cut-off point of Pleural fluid: Serum protein-carbonyl ratio to distinguish exudative and transudative pleural effusion

and mycobacterial pleural infections, and in pathogenesis of malignant pleural effusion. When exposed to noxious stimuli, it expresses Toll-like receptor (TLR) mediated recognition of pathogen associated molecular patterns. It releases several cytokines to activate adaptive immune responses. Pleural effusions occurs due to an imbalance in the dynamic interaction between junctional proteins, $\mathrm{n}$-cadherin and $\beta$-catenin, and phosphorylation of adherens junctions between PMCs, which is caused in part by vascular endothelial growth factor (VEGF) released by PMCs. ${ }^{31}$ Nitric oxide $(\mathrm{NO} \bullet$ ) synthesized by inducible nitric oxide synthase (iNOS) in activated PMC acts as an important host defence mechanism causing modification of bacterial proteins and lipids, deamination of bacterial DNA. It interacts with accessory protein targets; resulting in enzymatic inactivation or other protein malfunctions to initiate intracellular mycobacterial killing. ${ }^{32} \mathrm{PMC}$ mediated immunity is very much "non-specific" NO• contributes to the inflammatory response; leads to tissue leakage and damage, thus increasing vascular permeability. ${ }^{33}$ Induction of iNOS by endotoxin during inflammatory infectious processes produces abundant amount of $\mathrm{NO} \bullet$ for extended period. $\mathrm{NO} \bullet$ rapidly reacts with molecular oxygen and superoxide anion to form peroxynitrite, which in turn reacts with tyrosine residue of protein to form nitrotyrosine.

Peroxynitrite and nitrotyrosine together are called as reactive nitrogen intermediates (RNI). RNI has damaging effects on proteins converting them into protein carbonyls. ${ }^{34}$ Introduction of carbonyl group in proteins makes them susceptible to degradation by proteolytic 
enzymes leading to deficiency of proteins. It's hypothesised that carbonylated proteins may be selectively degraded if irreparable, aggregated or may influence the activities of signal transduction molecules to elicit cellular events. However, decrease in efficiency of proteolysis cause cellular content of oxidative modified proteins to increase in cells as seen in cases of exudative pleural effusion of Mycobacterium Tuberculosis origin..$^{35}$ The above mechanism provides the connecting link between protein carbonyl production and formation of exudative effusion as a squally of various diseases.

Transudative pleural effusion formation, on the other hand, is not related to local pleural pathology. They are produced primarily by an imbalance between the hydrostatic and oncotic pressures and this does not lead to the formation of reactive oxygen species. The degree of pulmonary venous hypertension is a major determinant of transudative pleural effusion formation in heart failure. ${ }^{36}$ The concentration of total protein leaking out of the microcirculation in pleural fluid is proportional to the degree of elevation of pulmonary capillary wedge pressure. ${ }^{37}$ Similarly, in transudative ascites secondary to portal hypertension, the serum protein concentration and degree of portal pressure determine the ascitic fluid protein concentration. ${ }^{38}$ Approximately 20 percent of patients with transudative pleural effusion caused by heart failure may fulfil the criteria for an exudative effusion after receiving diuretics. In these circumstances, neither protein nor albumin gradients individually should be the primary test used to distinguish transudative effusions from exudative effusions because they might result in the incorrect classification of a significant number of exudates. Only when we combine this with pleural fluid LDH levels, the accuracy and the likelihood ratio of correct classification increases. This is in sharp contrast to the increased carbonyl stress levels in exudates compared to transudates. ${ }^{39}$ A cut off value of ratio at 0.49 using protein carbonyl clearly distinguished between the basic fluid types without any ambiguity (Figure1).

Among the exudates, the gradient was found to be statistically higher among males compared to females (Table 2). This indirectly reflected that oxidatively modified, functionally altered proteins, accumulated more in serum and pleural fluid of male patients with exudative effusion compared to their female counterparts. Relevant systems and functions in the respiratory and circulatory system such as the protease/antiprotease balance, probably become dysfunctional more in males than in females due to the increased prevalence in males of various respiratory tract infections and malignancies, especially among smokers. No age group related difference was seen among the two gradients (Table 3). This implied that the statistical difference existent between these two gradients were more type specific (exudative/transudative) rather than due to age related changes in oxidative stress pattern.

An important limitation of our study was that not much difference was noticed in protein carbonyl levels in different disease entities in individual arms. A plausible explanation for this might be the fact that the method was validated to measure overall carbonyl stress in pleural fluids and is unable to identify subtle differences based on aetiology. Compared with previous studies, our study has several strengths. First, the method help better to categorize the occasional transudate misidentified as an exudate by Light's criteria only on the basis of a single biochemical parameter. Second it's intrinsically related and highlights the basic pathogenesis and mechanism involved in formation of exudative effusions in comparison to transudate formation. Third, protein carbonyl assays offer the advantage that no special or expensive equipment is required. As a result, they can be measured in pleural fluids in any normally equipped biochemistry laboratory. ${ }^{40}$

\section{Limitations of the study}

The study population was small in number. Multicentre study may be required in this regard to further sub classification of cases based on etiology.

Moreover it is not a prospective study. Hence the utility of these study parameters in assessment of prognosis in post treatment cases could not be assessed.

\section{CONCLUSION}

In our study we have shown that, irrespective of age and sex, $R_{e}$ is greater than $R_{t}$. Therefore we have a strong evidence to suggest that this parameter can be used to differentiate transudates and exudates on a routine basis.

\section{ACKNOWLEDGMENT}

The authors wish to acknowledge all the staff of the Dept. of Biochemistry, IPGMER \& SSKM Hospital, Kolkata for their support.

\section{REFERENCES}

1. Paddock FK. The diagnostic significance of serous fluid in disease. N Engl J Med. 1998; 223:1010-1015.

https://doi.org/10.1056/NEJM194012192232503

2. Broaddus VC and Light RW. What is the origin of pleural transudates and exudates? [Editorial] Chest.1992;102:658. 
https://doi.org/10.1378/chest.102.3.658

3. LightRW. Pleural diseases. fifth ed, Philadelphia: Lippincott;2007.

4. Porcel JM and Light RW. Diagnostic approach to pleural effusion in adults. Am Fam Physician. 2006; 73(7):1211-1220.

5. Kim JG, Sabbagh F, Santanam N, Wilcox JN, Medford RN and Parthasarathy S. Generation of a polyclonal antibody against lipid peroxide-modified proteins. Free Radic Biol Med. 1997; 23:251-259.

https://doi.org/10.1016/S0891-5849(96)00615-6

6. Chevion M, Berenshtein E and Stadtman ER. Human studies related to protein oxidation: protein carbonyl content as amarker of damage. Free Radic Res. 2000; 33: S99-S108.

7. Shacter E. Quantification and significance of protein oxidation in biological samples. Drug Metab Rev. 2000; 32: 307- 326. https://doi.org/10.1081/DMR-100102336

8. Beal MF. Oxidatively modified proteins in aging and disease. Free Radic Biol Med. 2002; 32(9):797-803. https://doi.org/10.1016/S0891-5849(02)00780-3

9. Chevian M, Berenshtein E and Stadtman ER. Human studies related to protein oxidation: protein carbonyl as marker of damage. Free Radic Res. 2000; 33:99-108.

10. Aruna $\mathrm{K}$ and Narayan AM. Relationship of nitric oxide and protein carbonyl in tuberculosis. Indian J Tuberc. 2008; 55: 138-144.

11. Lenz AG, Jorens PG, Meyer B, De Backer W, Van Overveld F, Bossaert L, et al. Oxidatively modified proteins in bronchoalveolar lavage fluid of patients with ARDS and patientsat-risk for ARDS Eur Respir J. 1999; 13(1):169-174.

https://doi.org/10.1034/j.1399-3003.1999.13a31.x

12. Pepper JR, Mumby $S$ and Gutteridge JMC. Sequential oxidative damage, and changes in iron-binding and iron oxidising plasma antioxidants during cardiopulmonary bypass surgery. Free Radic Res. 1994; 21:377-385.

https://doi.org/10.3109/10715769409056590

13. Quinlan GJ, Evans TW and Gutteridge JM. Oxidative damage to plasma proteins in adult respiratory distress syndrome. Free Radic Res. 1994; 20(5):289-298.

https://doi.org/10.3109/10715769409145628

14. Kremer R, Best LA, Savulescu D, Gavish M and Nagler RM. Pleural fluid analysis of lung cancervs benign inflammatory disease patients. British Journal of Cancer. 2010; 102:1180-1184. https://doi.org/10.1038/sj.bjc.6605607

15. Valdes L, Pose A, Suarez J, Gonzalez-Juanatey JR, Sarandeses A, Son Jose E, et al. Cholesterol: a useful parameter for distinguishing between pleural exudates and transudates. Chest. 1991; 99:507-513.

https://doi.org/10.1378/chest.99.5.1097

16. Meisel S, Shamis A, Thaler M, Nussinovitch N and Rosenthal T. Pleural fluid to serum bilirubin concentration ratio for separation of transudates from exudates. Chest. 1990; 98:141-144. https://doi.org/10.1378/chest.98.1.141

17. Pachon EG, Navas IP, Sanchez JF, Jimenez B and Custardoy J. Pleural fluid to serum cholinesterase ratio for the separation of transudates from exudates. Chest. 1996; 110:97-101. https://doi.org/10.1378/chest.110.1.97

18. Yetkin O, Tek I, Kaya A, Ciledag A and Numanoglu N. A simple laboratory measurement for discrimination of transudative and exudative pleural effusion: pleural viscosity. Respir Med. 2006; 100:1286-1290.

https://doi.org/10.1016/j.rmed.2005.10.010

19. Nandular KR, Hardie AH, Bollampally SR, Parmar JP and Hagspiel KD. Accuracy of computed tomography attenuation values in the characterization of pleural fluid: an ROC study. Acad Radiol. 2005; 12:987-991.

https://doi.org/10.1016/j.acra.2005.05.002

20. Chan MHM, Cow KM, Chan ATC, Leung CB, Chan LYS, Chow KCK, et al. Quantitative analysis of pleural cell free DNA as a tool for the classification of pleural effusions. Clin Chem. 2003; 49:740-745

https://doi.org/10.1373/49.5.740

21. Porcel MJ, Vives M, Esquerda A and Rivas CM. Pleural protein capillaryelectrophoresis for the separation of transudates and exudates. Clin Chem. 2001; 47:975-976.

https://doi.org/10.1093/clinchem/47.5.975

22. Papageorgiou E, Kostikas K, Kiropoulos T, Karetsi E, Mpatavanis $\mathrm{G}$ and Gourgoulianis I. Increased oxidative stress in exudative pleural effusions. Clin Chem. 2001; 47:975-976.

23. Schon T, Elmberger G, Negesse $Y$, Pando RH, Sundqvist $T$ and Britton S. Local production of nitric oxide in patients with tuberculosis. Int J Tuberc Lung Dis. 2004; 8(9): 966-970.

24. Fine $\mathrm{J}$. The biuret method of estimating albumin and globulin in serum and urine. Biochem J.1935; 29(3):799-803. https://doi.org/10.1042/bj0290799

25. Chakraborty S. Markers of Oxidative stress in hypertension and Pleural effusion-Towards clinical application of free radicals and antioxidants Free Radic Antioxi. 2012;2(2): i-ii https://doi.org/10.5530/ax.2012.2.ed

26. Manraj M, Kumari S, Pattnaik MR and Mahapatro PC. Pleural fluid MDA and serum-effusion albumin gradient in pleural effusion. Indian J Clin Bio. 2008; 23(1): 81-84. https://doi.org/10.1007/s12291-008-0019-1

27. Choe N, Tanaka S and Kagan E Asbestos fibers and interleukin-1 upregulate the formation of reactive nitrogen species in rat pleural mesothelial cells. Am J Respir Cell Mol Biol. 1998; 19: 226-236.

https://doi.org/10.1165/ajrcmb.19.2.3111

28. Upham BL and Wagner JG. Toxicant-induced oxidative stress in cancer. Toxicol Sci. 2001; 64: 1-3. https://doi.org/10.1093/ toxsci/64.1.1

29. Madebo T, Lindtjorn, B, Aukrust $P$ and Berge RK. Circulating antioxidants and lipid peroxidation products in untreated tuberculosis patients in Ethiopia. Am J Clin Nutr. 2003; 78, 117-122. https://doi.org/10.1093/ajcn/78.1.117

30. Antony VB and Mohammed KA. Pathophysiology of pleural space infections. Semin Respir Infect. 1999; 14:9-17.

31. Batra $\mathrm{H}$ and Antony VB. Pleural mesothelial cells in pleural and lung diseases. J Thorac Dis. 2015;7(6):964-980.

32. Nathan $C$ and Shiloh MU. Reactive oxygen and nitrogen intermediates in the relationship between hosts and microbial pathogens. Proc Natl Acad Sci USA. 2000; 97: 8841-8848. https://doi.org/10.1073/pnas.97.16.8841

33. Vallance $P$ and Moncada $S$. Role of endogenous nitric oxide in septic shock. New Horizons. 1993; 1: 77-87.

34. Ezekowitz RA, Sastry K, Bailly P and Warner A. Molecular characterization of the human macrophage mannose receptor: demonstration of multiple carbohydrate recognition-like domains and phagocytosis of yeasts in Cos-1 cells. J Exp Med. 1990; 172: $1785-1794$.

https://doi.org/10.1084/jem.172.6.1785

35. Beckman JS and Crow JP. Pathological implications of nitric oxide, superoxide and peroxynitrite formation. Biochem Soc Trans. 1993; 21: 330-334. https://doi.org/10.1042/bst0210330 
36. Wiener-Kronish JP, Matthay MA, Callen PW, Filly RA, Gamsu G and Staub NC. Relationship of pleural effusions to pulmonary hemodynamics in patients with congestive heart failure. Am Rev Respir Dis. 1985; 132:1253-1256.

37. Broaddus VC, Wiener-Kronish JP and Staub NC. Clearance of lung edema into the pleural space of volume-loaded anesthetized sheep. J Appl Physiol.1990; 68: 2623-2630.

https://doi.org/10.1152/jappl.1990.68.6.2623

38. Hoefs JC. Serum protein concentration and portal pressure determine the ascitic fluid protein concentration in patients with chronic liver disease. J Lab Clin Med. 1983; 102:260-273.

39. Porcel JM, Vives M, Vicente de Vera MC, Cao G, Rubio M and Rivas MC. Useful tests on pleural fluid that distinguish transudates from exudates. Ann Clin Biochem. 2001; 38:671-675. https://doi.org/10.1258/0004563011901082

40. Isabella DD, Rossib R, Giustarinib D, Milzania A and Colomboa R. Protein carbonyl groups as biomarkers of oxidative stress. Clinica Chimica Acta. 2003; 329: 23-38. https://doi.org/10.1016/S0009-8981(03)00003-2

\section{Authors' Contribution:}

RG-Concepts and definition of intellectual content; KM-Literature search, clinical studies; SM-Experimental studies, data acquisition and analysis; DB- Data and statistical analysis, manuscript preparation; SB-Manuscript review.

Work Attributed to:

IPGMER and SSKM Hospital, Kolkata, West Bengal, India

Orcid ID:

Dr. Raghumoy Ghosh - (1) http://orcid.org/0000-0003-3274-5149

Dr. Kheya Mukherjee - (iD http://orcid.org/0000-0002-3319-7829

Dr. Saumyajit Maiti - (D) http://orcid.org/0000-0002-1418-7991

Dr. Debojyoti Bhattacharjee - (1) http://orcid.org/0000-0001-5769-5817

Dr. Shubho Chowdhuri - (ib http://orcid.org/0000-0003-3881-4213

Source of Support: None, Conflict of Interest: None. 